\title{
GDF3 Gene
}

National Cancer Institute

\section{Source}

National Cancer Institute. GDF3 Gene. NCI Thesaurus. Code C101649.

This gene is involved in the regulation of cell differentiation. 